\title{
Application of Project Management in Ministerial Security Development Technical Paper
}

\author{
Carol Axten \\ Civil Engineering, \\ Project Management, \\ University of Maryland \\ caroljmcilwain@gmail.com
}

\section{Keywords}

International Ministerial

Security Development

(MSD), Program Management Office Structure, Integrated Management Plan, MSD in Iraq and Afghanistan
After the September 11, 2001 attack on the World Trade Center and the Pentagon, the U.S. Defense focus turned to FIGHTING TERRORISM THROUGHOUT THE WORLD. The U.S. entered into a conflict with Afghanistan to remove the Taliban government which supported Osama Bin Laden and insurgent training camps. In 2003, the U.S. expanded the "Global War on Terror" to include Iraq and the removal of Saddam Hussein and purge the country of Al Qaeda insurgents. In both situations, government functions were devastated and needed to be rebuilt. This paper discusses applying a strategic to tactical, multi-dimensional approach to project management to a Ministerial Security Development mission laying a foundational framework with developmental processes. Although this paper focuses on the Ministry of Defense (MoD), the same approach applies to other Security Ministries such as Ministry of Interior and National Department of Security. This paper does not cover the "fight" element of contingency operations. The project management approach utilizes business models adopted by the Pentagon to establish organization operations. The U.S's ability to establish effective MoD organizations in these regions is essential to a decreasing Department of Defense (DoD) budget particularly with Sequestration. Self-sufficiency means less manpower by the Coalition Security Assistance Force (CSAF). The lessons of Iraq and Afghanistan have shown that establishing Ministerial Security functional capability cannot be approached as a campaign plan. A project management approach provides the tools for business operations planning and allows for identifying and managing risks in a very uncertain environment. 


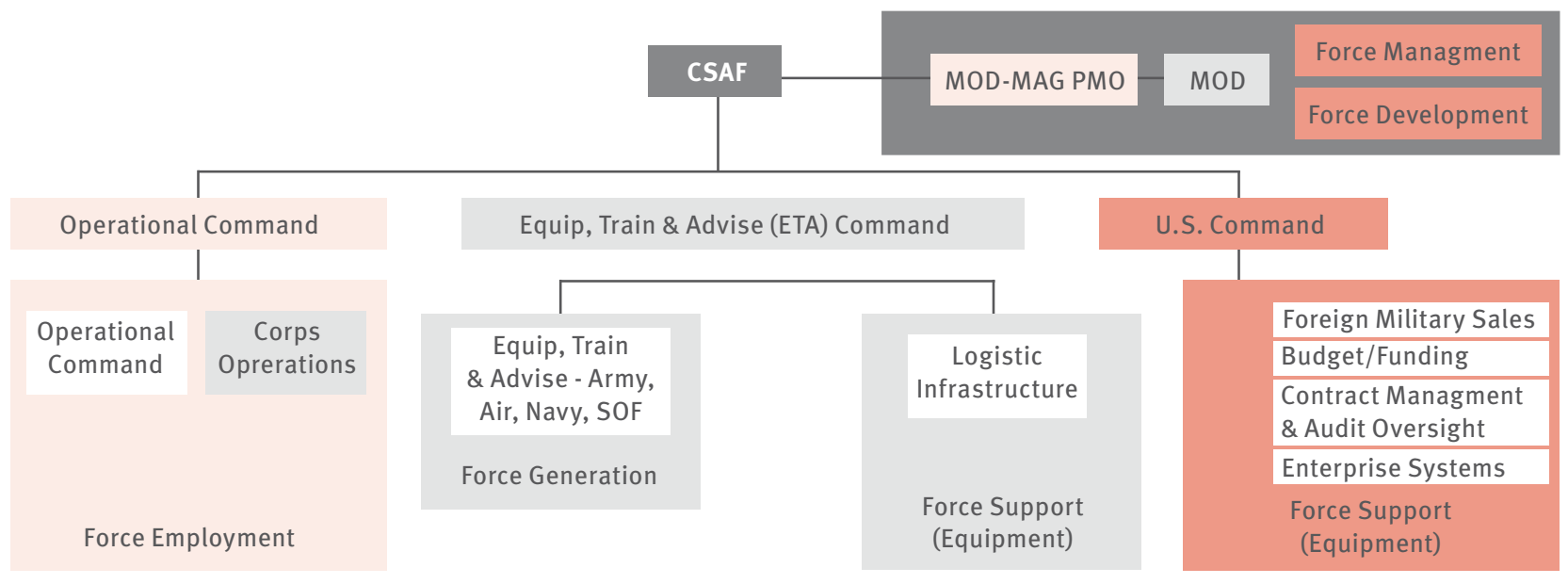

Specialized Competencies

\begin{tabular}{|l|l|l|}
\hline Administration & Inspector General & Military Operations \& Tactics \\
\hline Budget/Finance & Inteligence & Personal \& Education \\
\hline Construction & Leadership Development & Procurement \\
\hline Engineering & Legal & $\begin{array}{l}\text { Stractegic Communication \& Publcic } \\
\text { Affairs Office }\end{array}$ \\
\hline Facilities Managment & Logistics & Strategic Planning \& Policy \\
\hline Information Technology & Medical & Training \\
\hline
\end{tabular}

Figure 1

\section{Introduction}

The legitimacy of the Security Assistance Mission and in particular the Ministerial Security Development mission is addressed in the U.S. National Security Strategy (NSS) for 2010. As stated in the NSS,

"the United States and the international community cannot shy away from the difficult task of pursuing stabilization in conflict and post-conflict environments. In countries like Iraq and Afghanistan, building the capacity necessary for security, economic growth, and good governance is the only path to long term peace and security. But we have also learned that the effectiveness of these efforts is profoundly affected by the capacity of governments and the political will of their leaders. We will take these constraints into account in designed appropriate assistance strategies and will facilitate the kind of collaboration that is essential-within our government and with international organizations-in those instances when we engage in the difficult work of helping to bring conflicts to an end." (White House, 2010)

The NSS specifically addresses the need that development is a strategic, economic, and moral imperative requiring the focus on assisting the developing countries and their people to manage their security threats, introduce global economic expansion, and establish accountable and democratic institutions that support basic human needs (White House, 2010). This objective is recognized in both CSAF efforts in Iraq and Afghanistan.

As cited in the Master Ministerial Development Plan (MMDP), "the Ministerial Advisory Group (MAG) will develop the capabilities and capacity of the Ministry of Defense and General Staff in order to establish enduring institutions which can direct and sustain Afghan-led security operations." (Goodman, 2012).

\section{CSAF Structure}

The CSAF structure is broken into two elements: (1) equip, train, and advise and (2) Ministerial Leadership Development. This approach tends to separate (1) equipment, training and advising of the equipment from (2) the role of advising on standing up processes for the Defense Ministry to determine equipment and training needs and budget and execute for those needs. This approach establishes the Ministry foundation sooner but is higher risk for the Assisted Nation to effectively assume the responsibility having less of an understanding for why processes and practices are implemented. The effort done concurrently would provide better understanding by the Assisted Nation.

Planning needs to be accomplished in conjunction with the Assisted Nation (Nation $\mathrm{X}$ for this paper) to facilitate "buy-in" and processes and practices meet the long term needs of the nation 


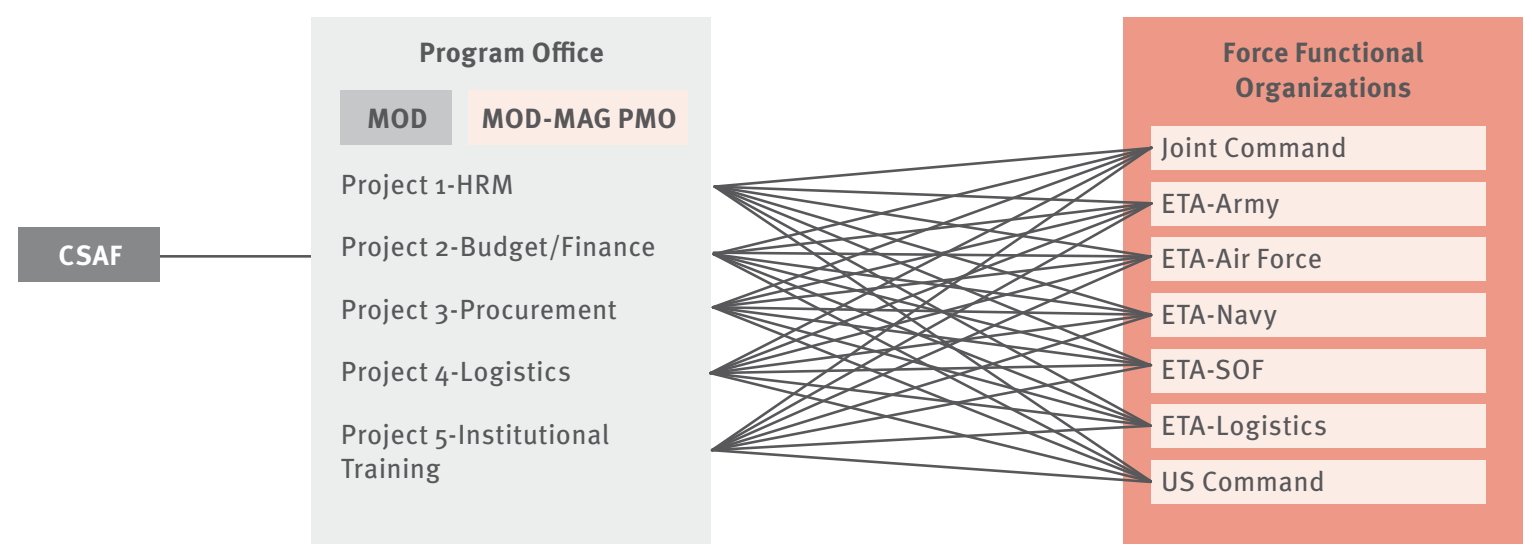

Figure 2

for sustaining their security and stability. The approach for managing projects in a dynamic environment, Simultaneous Management, suits Ministerial Security Development over the traditional project management approach. The skill of negotiation and ability to influence is paramount to creating "buy-in" with the nation.

The CSAF Organization Structure (Figure 1) needs to accommodate a critical alignment with the MoD leadership to jointly establish the foundation together. This alignment is accomplished through the Ministerial Advisory Group (MAG). A Program Management Office Structure, typically used in the DoD for acquisition and development of weapon systems, encompasses three primary elements:
(1) Matrix of projects and competency support, (2) an Integrated Plan, and (3) Hierarchy Milestone Reviews. The MAG can assume the role of a Program Management Office with responsibility for the integration of all tasking across the CSAF. Figure 1.

A Project Management Office manages a single project; a Program Management Office (PMO) manages multiple projects. A Portfolio Management Office manages several programs and is typical of a DoD Program Executive Office (PEO). Management attention between the office types changes from a focus of execution within a project and tools of basic project management to management across multiple programs and the breadth and complexity of meeting the organization's mission and multiple stakeholders' objectives. Ministerial Security Development fits the model of a PMO managing several projects which have defined interrelationships. With the incorporation of multiple PMOs, the mission at the CSAF level becomes a PEO. The complexity of a PEO is driven by the increase in external focus on impacts, constraints, consequences, and results. In order to better manage these multi-faceted elements, knowledge areas such as Strategic Management, Governance Management, Performance Management, Communication Management, and Risk Management become critical to effective Portfolio Management.

PMO

\begin{tabular}{|c|c|c|c|c|c|c|c|}
\hline & $\begin{array}{l}\text { Joint } \\
\text { Command }\end{array}$ & ETA-Army & ETA-Air Force & ETA-Navy & ETA-SOF & $\begin{array}{c}\text { ETA- } \\
\text { Logistics }\end{array}$ & US Command \\
\hline $\begin{array}{l}\text { Project } 1 \\
\text { Strategy \& Policy }\end{array}$ & $x$ & $x$ & $x$ & $x$ & $x$ & $x$ & $x$ \\
\hline $\begin{array}{l}\text { Project } 2 \\
\text { HRM }\end{array}$ & $x$ & $x$ & $\mathrm{x}$ & $x$ & $\mathrm{x}$ & $\mathrm{x}$ & $x$ \\
\hline $\begin{array}{l}\text { Project } 3 \\
\text { Budget/Finance }\end{array}$ & $x$ & $\mathrm{x}$ & $\mathrm{x}$ & $x$ & $\mathrm{x}$ & $\mathrm{x}$ & $\mathrm{x}$ \\
\hline $\begin{array}{l}\text { Project } 4 \\
\text { Procurement }\end{array}$ & $x$ & $x$ & $\mathrm{x}$ & $x$ & $\mathrm{x}$ & $\mathrm{x}$ & $x$ \\
\hline $\begin{array}{l}\text { Project } 5 \\
\text { Logistic }\end{array}$ & $x$ & $x$ & $x$ & $x$ & $\mathrm{x}$ & $\mathrm{x}$ & $x$ \\
\hline $\begin{array}{l}\text { Project } 6 \\
\text { Institutional Training }\end{array}$ & $x$ & $x$ & $x$ & $x$ & $\mathrm{x}$ & $\mathrm{x}$ & $x$ \\
\hline
\end{tabular}

Figure 3 


\begin{tabular}{|c|c|c|c|c|c|c|c|}
\hline & $\begin{array}{c}\text { Joint } \\
\text { Command }\end{array}$ & ETA-Army & ETA-Air Force & ETA-Navy & ETA-SOF & ETA-Logistics & US Command \\
\hline & $\begin{array}{l}\text { Columns with } \\
\text { Competencies }\end{array}$ & $\begin{array}{l}\text { Columns with } \\
\text { Competencies }\end{array}$ & $\begin{array}{l}\text { Columns with } \\
\text { Competencies }\end{array}$ & $\begin{array}{l}\text { Columns with } \\
\text { Competencies }\end{array}$ & $\begin{array}{l}\text { Columns with } \\
\text { Competencies }\end{array}$ & $\begin{array}{l}\text { Columns with } \\
\text { Competencies }\end{array}$ & $\begin{array}{l}\text { Columns with } \\
\text { Competencies }\end{array}$ \\
\hline $\begin{array}{l}\text { Project } 1 \\
\text { Strategy \& Policy }\end{array}$ & $x$ & $x$ & $x$ & $x$ & $x$ & $x$ & $x$ \\
\hline $\begin{array}{l}\text { Project } 2 \\
\text { HRM }\end{array}$ & $x$ & $x$ & $x$ & $x$ & $x$ & $x$ & $x$ \\
\hline $\begin{array}{l}\text { Project } 3 \\
\text { Budget/Finance }\end{array}$ & $x$ & $x$ & $x$ & $x$ & $x$ & $x$ & $x$ \\
\hline $\begin{array}{l}\text { Project } 4 \\
\text { Procurement }\end{array}$ & $x$ & $x$ & $x$ & $x$ & $x$ & $x$ & $x$ \\
\hline $\begin{array}{l}\text { Project } 5 \\
\text { Logistic }\end{array}$ & $x$ & $x$ & $x$ & $x$ & $x$ & $x$ & $x$ \\
\hline $\begin{array}{l}\text { Project } 6 \\
\text { Institutional } \\
\text { Training }\end{array}$ & $x$ & $x$ & $x$ & $x$ & $x$ & $x$ & $x$ \\
\hline
\end{tabular}

Figure 4

\section{Matrix Structure}

An Integrated Management Plan (IMP) details the tasking for each CSAF Force Functional Command (FFC) and the relationships or linkages that exist creating the integration piece. The PMO manages the integration of several projects for establishing the Core Capability of the MoD. As a minimum, these would be the foundational processes or systems for managing Nation $X$ 's Military Force: Strategic Planning \& Policy, Human Resource Management, Budget/Financial, Procurement, Logistics, and Institutional Training. Figure 2 depicts the complexity of multiple FFCs supporting multiple projects. Applying linear presentation to a matrix structure can appear chaotic and difficult to follow alignment of project to FFC participants. Figure 2

Figure 3 presents the same complexity but in a two-dimensional matrix chart creating order and alignment. This visual representation conveys the cross-functional element of a matrix structure through a table of projects aligned with FFCs. Figure 2 and 3 depict the difference in approach for visually depicting the same information.

By adding the competencies of the
FFCs, the structure becomes a threedimensional matrix represented in a two-dimensional form in Figure 4. The foundational systems (projects) may have a common thread for data collection, analysis, and feedback loop to apply the information in the next iteration of operations. The common thread element optimizes on common data collection for multiple applications. Competency participants that cross projects ensure this common thread to leverage commonality of systems to the greatest extent. Figure 4

To add further complexity, initiatives such as literacy, counter-corruption, gender integration, and civilianization require a comprehensive approach in planning and implementation. These cross-cutting initiatives cross projects, FFCs, and competencies creating a fourth dimension to the structure and execution Figure 5.

\section{Integrated Management Plan}

The PMO defines the guidance for the FFCs to develop their piece of the IMP (Figure 6) through the collaborated agreements with Nation X's MoD. The PMO monitors the progress of the IMP activities and resolves cross-functional issues. Each FFC manages their IMP activities and coordinates with PMO for the protocol for interaction with Nation X's MoD. Figure 6

A Memorandum of Understanding (MOU) can be drafted by each FCC to address the conditions needed for interaction and rationale with Nation X; both PMO and FFC leadership sign the MOU. The MOU allows each FFC to operate more autonomously yet still within defined guidelines. This is prudent in Ministerial Security Development to ensure a single message and direction is conveyed to Nation X's Government leadership. When the message appears ambiguous, Nation X's Government leadership tends to exploit the opportunity to misinterpret the message to their advantage. The more players involved the greater the risk that the CSAF's direction is misinterpreted by Nation $X$. This is a recognized risk in International Relations and is mitigated by a single message and direction of CSAF through PMO.

Utilizing a project management approach to Ministerial Security Development would ensure continuity of execution through the IMP built with Summary Tasks. Detailed 


\begin{tabular}{|c|c|c|c|c|c|c|c|}
\hline & $\begin{array}{c}\text { Joint } \\
\text { Command }\end{array}$ & ETA-Army & ETA-Air Force & ETA-Navy & ETA-SOF & ETA-Logistics & US Command \\
\hline & $\begin{array}{l}\text { Columns with } \\
\text { Competencies }\end{array}$ & $\begin{array}{l}\text { Columns with } \\
\text { Competencies }\end{array}$ & $\begin{array}{l}\text { Columns with } \\
\text { Competencies }\end{array}$ & $\begin{array}{l}\text { Columns with } \\
\text { Competencies }\end{array}$ & $\begin{array}{l}\text { Columns with } \\
\text { Competencies }\end{array}$ & $\begin{array}{l}\text { Columns with } \\
\text { Competencies }\end{array}$ & $\begin{array}{l}\text { Columns with } \\
\text { Competencies }\end{array}$ \\
\hline $\begin{array}{l}\text { Project } 1 \\
\text { Strategy \& } \\
\text { Policy }\end{array}$ & $x$ & $x$ & $x$ & $x$ & $x$ & $x$ & $x$ \\
\hline $\begin{array}{l}\text { Project } 2 \\
\text { HRM }\end{array}$ & $x$ & $x$ & $x$ & $x$ & $x$ & $x$ & $x$ \\
\hline $\begin{array}{l}\text { Project } 3 \\
\text { Budget/ } \\
\text { Finance }\end{array}$ & $x$ & $x$ & $x$ & $x$ & $x$ & $x$ & $x$ \\
\hline $\begin{array}{l}\text { Project } 4 \\
\text { Procurement }\end{array}$ & $x$ & $x$ & $x$ & $x$ & $x$ & $x$ & $x$ \\
\hline $\begin{array}{l}\text { Project } 5 \\
\text { Logistic }\end{array}$ & $x$ & $x$ & $x$ & $x$ & $x$ & $x$ & $x$ \\
\hline $\begin{array}{l}\text { Project } 6 \\
\text { Institutional } \\
\text { Training }\end{array}$ & $x$ & $x$ & $x$ & $x$ & $x$ & $x$ & $x$ \\
\hline
\end{tabular}

Figure 5

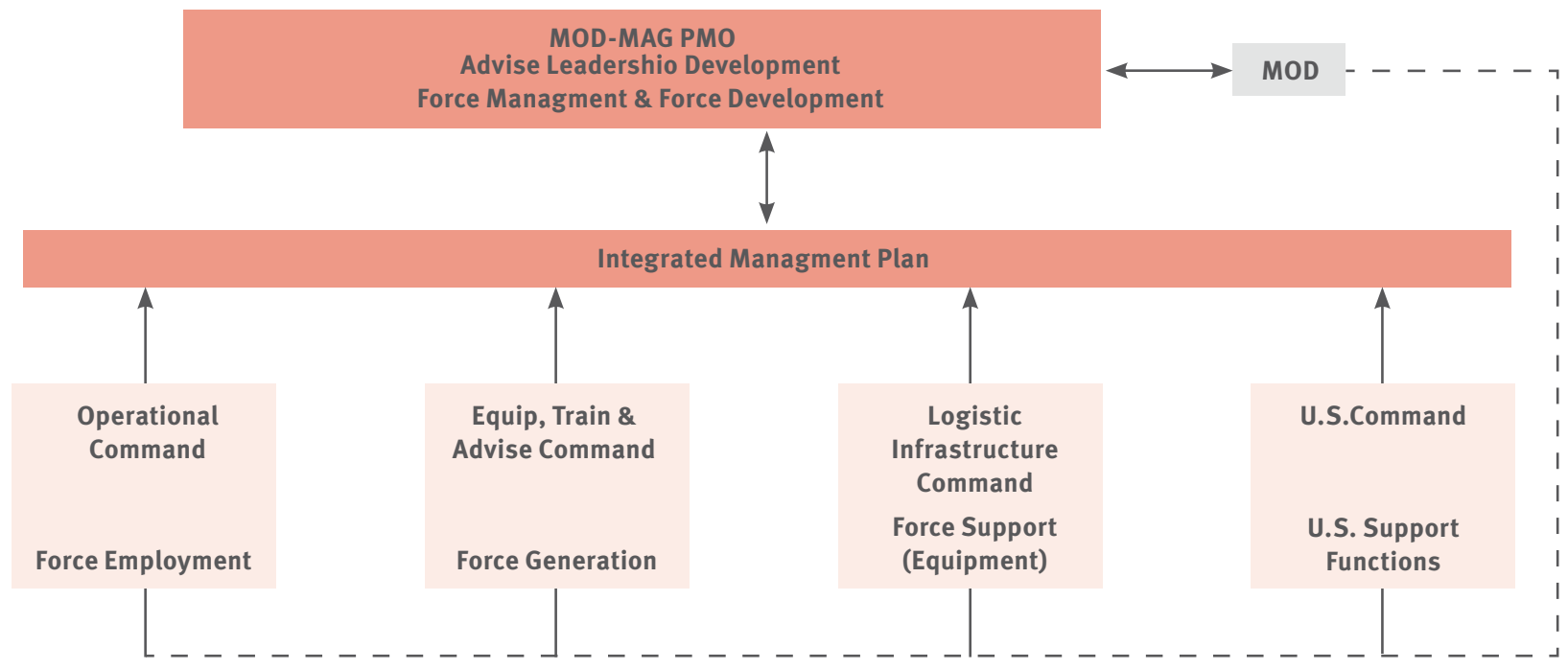

Figure 6

planning would occur in 6 month rolling wave increments. Project management elements of risk management can be applied to manage the uncertainty inherent in building Nation X's Defense Government Base while at war. Risks such as availability of electricity, internet connectivity, culturally differing perspectives can be identified and mitigated using standard risk management techniques. This approach would allow for budgeting of Summary Tasks and the tracking of cost performance associated with those tasks in addition to schedule performance. Re-allocation of resources can be effectively managed based on the ability to meet capability parameters in some areas and respond to challenges in others.

An IMP would provide continuity to reduce the inefficiency caused by the 


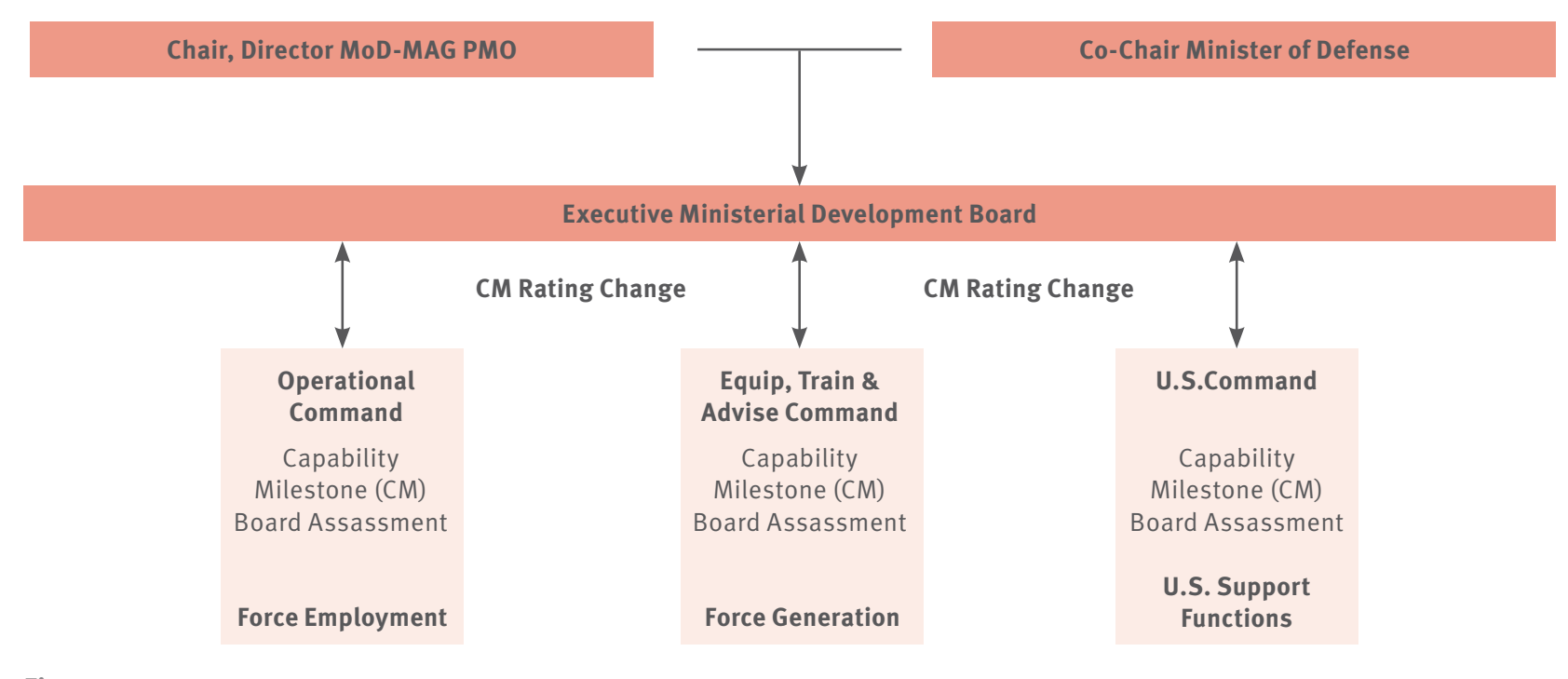

Figure 7

turnover of personnel. Few companies could stay in business with $100 \%$ turnover every year and possibly $50 \%$ turnover every 6 months. An IMP with Summary Tasks scoped with Nation $\mathrm{X}$ would lay the foundation for detailed planning occurring in the 6 month increments. Especially with multi-national support, good planning can reduce the friction created from ambiguous objectives and the need to "reinvent the wheel" throughout the mission.

\section{Capability Milestones}

To evaluate the progress of Nation $X$, metrics would be developed using quantitative measures to the greatest extent. Qualitative measures should be applied based on understanding the limitations on interpretation. Significant movement in a rating capability would be presented to an Executive Ministerial Development Board (EMDB) (Figure 7) which is chaired by the Director for the PMO with leadership of all FFC. The EMDB would collectively determine if a Capability Milestone (CM) has been achieved. In the case when consensus cannot be reached, the Chairman has the final decision. At the beginning of the Ministerial Security Development effort, the EMDB would be Coalitionled participation. As Nation X's leadership reached pre-planned levels of capability, the participation would include Nation $X$ and eventually shift to Co-Chairing the EMDB with joint participation in reviews and decisions. Figure 7

In the early stages, quarterly reviews should be conducted by the Director of the PMO to the Ministerial Leadership: Minister of Defense, First Deputy Minister, Chief of General Staff, and Vice Chief of General Staff to convey the progress and areas of concern. As progress is made in Ministerial Development Leadership capability, the shift would occur to the Minister of Defense ultimately briefing the Director for the PMO. The IMP should include the roadmap in transition of responsibility of the EMDB as part of the PMO's Summary Tasks.

Each FFC would track the progress of the tasks, including how each of their areas are doing on literacy, countercorruption, gender integration, and civilianization both CSAF and partnering Nation $\mathrm{X}$ to meet the Capability Milestone. Building infrastructure is often part of building the capability in a Developing Government. For example, establishing institutional training includes the physical building (construction), curriculum (training), and administration management (administration). The IMP includes the tasks of the CSAF for infrastructure projects, tasks associated with Nation $X$, and all linked to Nation X's Capability Milestone. Nation $\mathrm{X}$ is required to provide land for the building; this would be a Summary Task assigned to Nation $\mathrm{X}$ with linkages to CSAF's design and construction of building. This link creates the bond between the CSAF and Nation $X$ in truly creating a partnership, one side cannot achieve success without the other. An IMP can predict cost and schedule results for the entire project or program at any point in time.

Another example is logistics, warehouses (construction) for storage would need to be designed and constructed, land provided (Assisted Nation), and processes for receiving goods, storing, requisitioning, and distributing those goods (logistics) established. Once the logistical foundation is established and data is collected, forecasting is accomplished using the historic data and a feedback loop can trigger automatic ordering at pre-determined points (contracting). Identifying personnel from Nation $\mathrm{X}$ and training them links the effort to the HRM system (personnel \& education). In both examples, multiple competencies play into achieving the End Result. These competencies will cross FFC as projects are executed from Strategic to Operational to Tactical levels to meet full security mission. The IMP tracks 
performance and predicts cost and schedule results for End State at any point in time.

The initiatives of literacy, countercorruption, gender integration, and civilianization would be included in IMP tasks and Capability Milestone rating for all projects, FCCs, and competencies. This method creates a comprehensive approach for initiatives to drive synergistic results to achieve security and stability of the nation; synergistic results equate to the whole being greater than the sum of the parts.

\section{Conclusion}

In the report Learning from Iraq: A Final Report from the Special Inspector General for Iraq Reconstruction, there were seven Final Lessons for Iraq summarized:

1. Create an integrated civilian-military office to plan, execute, and be accountable for contingency rebuilding activities during stabilization and reconstruction operations.

2. Begin rebuilding only after establishing sufficient security, and focus on small programs and projects.

3. Ensure full host-country engagement in program and project selection, securing commitments to share costs (possibly through loans) and agreements to sustain completed projects after their transfer.

4. Establish uniform contracting, personnel, and information management systems that all Self-Regulatory Organizations (SRO) participants use.

5. Require robust oversight of SRO activities from the operation's inception.

6. Preserve and retire programs developed in Iraq, like the Commander's Emergency Response Program and the Provincial Reconstruction Team program that produced successes when used judiciously.

7. Plan in advance, plan comprehensively and in an integrated fashion, and have the backup plans ready to go. (Bowen, 2013)
As cited in the above lessons learned, the need for a comprehensive approach, an integrated plan, and the participation in planning with the Assisted Nation are primary elements to success of the CSAF mission. This paper provides the concept of a Program Management Office Structure utilizing the Ministerial Advisory Group as the PMO due to their role as the advisory link to the Ministry of Defense. The PMO will collaterally compile and manage the IMP while executing Ministerial Development Leadership. The paper also portrays the complexity of structure, planning, and implementation through a multi-dimensional approach to achieve success in Ministerial Security Development. This approach provides both effectiveness and efficiency in implementation over establishing separate PMO and MoDMAG organizations.

The results of years of military presence in Iraq and Afghanistan reduced violence; however, this reduction is not truly tested until the external military presence is gone and the Nation must now sustain the stability and provide for their own security. The death toll in Iraq has exceeded 8000 for 2013 returning to the pre-U.S. military surge which significantly reduced and then leveled violence from 2009-2011 (Gamel, 2013). With neighboring Syria in a civil war and Libya still in turmoil from the civil war initiated during the Arab Spring 2011 and the removal of Colonel Muammar Gaddafi, the Middle East and Southwest Asia will remain on the International Security radar for some time. Although future security assistance initiatives are expected to be less extensive as Iraq and Afghanistan, the need to bolster the MoD of foreign countries to provide security and stability for the nation will be a mission for the DoD for many years. The lessons in the execution of Iraq and Afghanistan provide insight into the long-term approach for Ministerial Security Development in the application of smaller contingency operations.

\section{References:}

Bowen, S. (2013) Learning from Iraq: A Final Report from the Special Inspector General for Iraq Reconstruction, Washington, DC.

Gamel, K and Yacoub, S., (2013), "UN in Iraq Worried About Uptick in Bodies Found", $A B C$ News Baghdad available at http://abcnews. go.com/International.

Goodman, J. Col (revision 2012), and Heiden, C. Dr. and Dryden, G. (original, 2011), Master Ministerial Development Plan, NATO Training Mission-Afghanistan/Combined Security Transition Command-Afghanistan, Afghanistan.

White House, (2010), National Security Strategy, Washington, DC. 